PROCEDIA

Studi Kasus dan Intervensi Psikologi

ISSN:2302-1462

Volume 8(1) 26-36, Maret 2020

DOI: $10.22219 /$ procedia.v4i1.11964

\title{
Meningkatkan keterampilan sosial dengan social skill training pada anak autis
}

Fatimah Azzahra, Universitas Muhammadiyah Malang, Malang, Indonesia

Korespondensi:

Fatimah Azzahra, Universitas Muhammadiyah Malang, e-mail: fatimaazahra218@gmail.com

\begin{abstract}
Riwayat artikel
Naskah diterima:

$06 / 12 / 2019$

Revisi diterima:

14/01/2020

Naskah disetujui:

04/03/2020

Abstrak

Satu kesulitan umum yang dialami oleh anak Autisme Spectrum Disorder (ASD) adalah ketidakmampuan untuk berinteraksi dengan orang-orang di sekelilingnya baik secara verbal maupun nonverbal, khususnya dalam hal keterampilan sosialnya. Studi kasus ini bertujuan untuk meningkatkan keterampilan sosial anak ASD dengan cara pemberian intervensi social skill training. Asesmen yang digunakan adalah wawancara, observasi, Children Behavior Checklist (CBCL), Coloured Progressive Matrices (CPM) dan Vineland Social Maturity Scale (VSMS). Setelah latihan diberikan menunjukkan bahwa intervensi keterampilan sosial mampu meningkatkan keterampilan sosial anak. Beberapa indicator peningkatan itu ditunjukkan dengan peningkatan subjek dalam berinisiatif menyapa orang lain dengan tos dan bersalaman.

Kata kunci: Autism Spectrum Disorder, keterampilan sosial, social skills training, komunikasi verbal, komunikasi nonverbal.
\end{abstract}

\section{Latar Belakang}

Autis Spectrum Disorder (ASD) merupakan salah satu fenomena yang cukup banyak terjadi, terutama di Indonesia. ASD sendiri semakin banyak di Indonesia. Hal tersebut tersebut didukung dengan semakin bertambahnya angka prevalensi penderita gangguan autisme di Indonesia dari tahun ke tahun (Desiningrum, 2016). Belum ada teori yang dapat menjelaskan sepenuhnya mengenai penyebab ASD atau penurunan spesifik yang ditunjukkan oleh orang-orang dengan ASD. Heterogenitas ASD berasal dari banyak interaksi neuropsikologis, genetik, dan lingkungan yang mendasari berbagai kelompok gejala dalam spektrum (Gelbar \& Buggey, 2012). Namun beberapa peneliti menyatakan bahwa mutasi DNA yang hilang atau terduplikasi pada kromosom 16 dapat meningkatkan kemungkinan seorang anak menderitas ASD hingga 100 kali lipat (Jhon, 2012).

Autisme sendiri merupakan gangguan yang meliputi area kognitif, emosi, perilaku, sosial, termasuk juga ketidakmampuan untuk berinteraksi dengan orang-orang di sekelilingnya baik secara verbal maupun nonverbal (Desiningrum, 2016; Jhon, 2012). Selain itu ASD melibatkan defisit dalam timbal balik sosial, bahasa, dan komunikasi, serta perilaku berulang dan/atau 
minat stereotip (Gelbar \& Buggey, 2012). Individu dengan ASD juga memberikan respon yang tidak biasa terhadap paparan indra sensoris (Jhon, 2012). Individu dengan ASD sangat bervariasi dalam hal kelebihan dan kelemahan mereka. Beberapa individu dengan ASD menunjukkan kesulitan kognitif yang signifikan, sedangkan pada individu lain tingkat kognitifnya berfungsi dengan relatif tinggi, meskipun terdapat berbagai defisit sosial. Dengan demikian, gejala yang terkait dengan ASD digambarkan sebagai heterogen, baik dalam agregat gangguan yang terdiri dari spektrum, serta berbagai kemampuan fungsional dalam setiap gangguan spesifik (Gelbar \& Buggey, 2012).

Salah satu hal yang mengalami penurunan pada individu dengan ASD adalah keterampilan sosialnya. Keterampilan sosial merupakan kemampuan anak untuk berinteraksi dengan orang lain pada konteks sosialnya (Suharsiwi, 2015). Keterampilan sosial dapat berupa perilaku spesifik yang menghasilkan interaksi sosial positif dan mencakup perilaku komunikasi interpersonal verbal yang diperlukan dan efektif (Rao, Beidel, \& Murray, 2008). Gangguan sosial pada individu dengan ASD beragam dan melibatkan bicara, konvensi linguistik dan interaksi antarpribadi (Williams, Kathleen, \& Scahill, 2007).

Sosialisasi dan kemampuan untuk berinteraksi dengan orang lain sangat penting dalam kehidupan manusia, yang membutuhkan keterampilan sosial. Sayangnya, gangguan keterampilan sosial tidak hanya menghambat perkembangan anak tetapi juga mengarah pada penolakan dan penerimaan oleh teman, teman sebaya, dan orang dewasa, serta kesepian dan isolasi. Kelemahan lain dari keterampilan sosial yang terganggu termasuk kemajuan akademik yang lemah, kegagalan sosial, kecemasan, depresi, pelecehan, hambatan untuk hubungan sosial, dan isolasi sosial (Golzari \& Alamdarloo, 2015).

Ada beberapa gejala umum mengenai permasalahan sosial pada individu dengan ASD, diantaranya ialah kesulitan mengorientasikan rangsangan sosial, memahami ekspresi wajah, dan menanggapi kesulitan orang lain. Individu dengan ASD juga mengalami kesulitan menggunakan tatapan untuk berkomunikasi, memulai interaksi, menggunakan salam yang sesuai, membangun joint attention, menghargai humor konvensional, gangguan pragmatik sosial (mis., turn-take dalam percakapan dan kemampuan untuk mengambil perspektif pendengar), prosodi bicara yang buruk (mis. naik turunnya nada suara dan infleksi yang membantu komunikasi verbal), kecenderungan untuk memikirkan topik-topik tertentu, kesulitan memahami dan mengekspresikan emosi, dan kesulitan menafsirkan bahasa nonliter seperti sarkasme dan metafora (Weiss \& Harris, 2001; Williams et al., 2007).

Sosialisasi dan kemampuan untuk berinteraksi dengan orang lain adalah keterampilan yang sangat penting dalam kehidupan, Anak-anak dengan ASD memiliki gangguan serius dalam hal ini. Individu dengan ASD menderita konsekuensi langsung dan tidak langsung terkait dengan defisit interaksi sosial. Remaja dengan ASD sering melaporkan keinginan untuk interaksi sosial yang lebih banyak, dan juga mungkin mengemukakan dukungan sosial yang buruk dan lebih kesepian daripada rekan-rekan mereka yang berkembang seperti biasa (Williams et al., 2007).

Untuk anak-anak dengan gangguan ini, defisit keterampilan sosial dapat mempengaruhi interaksi dengan keluarga, teman sebaya, dan orang dewasa lainnya. Pada gilirannya, keterampilan sosial yang terbatas dapat mempengaruhi kemampuan mereka untuk mencapai tonggak perkembangan yang normal dan membangun hubungan dengan keluarga dan teman yang memuaskan (Rao et al., 2008). Bila dibandingkan dengan anak-anak sebayanya, anak-anak dan remaja dengan ASD mungkin berisiko lebih tinggi untuk mendapat penolakan teman sebaya dan isolasi sosial. Ada juga bukti bahwa defisit keterampilan sosial pada remaja dengan ASD berkontribusi terhadap prestasi akademik dan pekerjaan. Hal ini dapat menyebabkan masalah suasana hati dan kecemasan kemudian dalam perkembangan (Williams et al., 2007).

Mengembangkan keterampilan sosial anak autis dapat menumbuhkan kepercayaan diri mereka (Suharsiwi, 2015). Anak-anak yang bisa berbicara biasanya lebih mudah untuk 
menirukan perintah dan belajar berbagai keterampilan sosial dibandingkan dengan anak yang belum. Anak-anak yang masih menggunakan bahasa nonverbal, dapat dikembangkan perilaku sosialnya seperti bersalaman, tersenyum, dan isyarat sosial lainnya (Suharsiwi, 2015).

Banyak tantangan dalam merawat anak-anak dengan autisme, dan para peneliti harus terus-menerus mengeksplorasi berbagai prosedur pengajaran. Salah satu prosedur yang telah banyak mendapat perhatian dalam literatur adalah modeling. Metode ini umumnya melibatkan prosedur dimana anak mengamati orang lain yang terlibat dalam perilaku yang ditargetkan. Penelitian telah menemukan bahwa anak-anak dengan masalah perkembangan belajar dengan mudah melalui modeling. Belajar melalui observasi juga penting bagi anak-anak autis di mana pembelajaran didapat secara alami melalui menonton dan meniru model (Weiss \& Harris, 2001).

Penelitian telah menunjukkan bahwa modeling tidak hanya mengajarkan perilaku baru kepada anak-anak autisme tetapi juga dalam mempromosikan, menggeneralisasi dan memeliharaan perilaku ini (Charlop-christy, Le, \& Freeman, 2000). Modeling merupakan salah satu tahapan dalam pelatihan keterampilan sosial. Pelatihan keterampilan sosial memiliki 4 tahapan yang terdiri dari modeling, roleplay, performance feedback dan transfer training (Ramdhani, 1994). Program pelatihan keterampilan sosial dirancang untuk mengajarkan anak-anak keterampilan yang diperlukan untuk mengarahkan lingkungan sosial mereka. Keterampilan ini memungkinkan anak untuk berasimilasi ke dalam kelompok teman sebaya dan juga berinteraksi dengan orang dewasa yang dikenal maupun tidak dikenal. Beberapa penelitian telah meninjau keberhasilan literatur untuk program pelatihan keterampilan sosial untuk anak-anak dengan autisme (Rao et al., 2008). Oleh karena itu, intervensi pelatihan keterampilan sosial sesuai diberikan untuk meningkatkan keterampilan sosialnya. Intervensi ini menargetkan perilaku menyapa dan bersalaman.

\section{Metode Asesmen}

Asesmen untuk penegakan diganosa yang tepat dengan mengetahui gejala gangguan dan permasalahan yang dialami dilakukan melalui serangkaian metode antara lain wawancara, observasi dan tes psikologi. Wawancara dilakukan terhadap orang tua dan guru subjek untuk memperoleh informasi lebih mendalam tentang gejala gangguan serta riwayat permasalahan yang subjek alami. Observasi dilakukan untuk memperoleh informasi perilaku dan aktivitas subjek untuk mementukan diagnosa gangguan dan permasalahan subjek.

Tes psikologi yang diberikan ialah Children Behavior Checklist (CBCL), Vineland Social Maturity Scale (VSMS), dan tes intelegensi Coloured Progressive Matrices (CPM). CBCL diberikan untuk mengetahui perilaku subjek dan menentukan gejala serta permasalahan yang dialami. CPM dilakukan untuk memastikan bahwa subjek bukan anak dengan disabilitas intelektual. VSMS diberikan untuk mengetahui permasalahan utama subjek yaitu keterampilan sosial subjek.

\section{Presentasi Kasus}

Subjek (7 tahun) merupakan siswa TKLB. Ayah subjek bekerja sebagai karyawan dan ibunya bekerja sebagai ibu rumah tangga. Subjek memiliki seorang kakak perempuan yang duduk di kelas 6 SD. Subjek memiliki kecerdasan yang tergolong superior. Subjek memiliki masalah terbesar dalam thought problems. Pada aspek thought problems, didapati bahwa subjek kurang tidur dibandingkan dengan anak-anak seusianya. Subjek menunjukkan obsesi akan beberapa hal seperti handphone, playdoh, benda-benda yang berputar, selain itu Subjek juga suka melihat ke arah ventilasi yang memantulkan cahaya. Terkadang Subjek melihat pajangan yang ada di kelas dan berhenti ketika guru memanggil namanya. Selain itu Subjek juga menunjukkan perilaku mencubit anggota tubuh baik dirinya maupun orang lain. Subjek juga menunjukkan perilaku yang aneh seperti memlihat hal-hal yang tidak nampak, berbicara bahasa isyarat, dan menulis 
dengan menggabungkan huruf dan gambar. Hal-hal tersebut menjadi pendukung diagnosa untuk menyatakan bahwa Subjek merupakan anak dengan gangguan spektrum autis.

Subjek memeliki kematangan sosial yang tidak sesuai dengan usianya terutama dalam hal sosialisasinya. Subjek belum bisa bermain dengan anak-anak lain, atau bermain sandiwara yang seharusnya bisa dilakukan oleh anak berusia 3 hingga 4 tahun. Subjek kurang bisa mempertahankan kontak mata untuk waktu yang lama, dan sering duduk menyendiri saat jam istirahat. Subjek juga memiliki permasalahan pada komunikasi baik verbal maupun nonverbal, serta menggunakan kata yang tidak dapat dimengerti orang lain. Subjek juga mengalami keterlambatan pada komunikasi, dimana kemampuan bicara (verbal) Subjek masih sangat kurang. Permasalahan ini sudah pernah dibawa ke dokter untuk memeriksakan telinga, namun Subjek dinyatakan tidak memiliki permasalahan apapun pada telinganya.

Pada masa kehamilan Subjek, ibunya tidak pernah mengalami hal yang berbeda atau penyakit selain batuk dan pilek, serta tidak pernah mengkonsumsi obat-obatan selama hamil. Ketika lahir, Subjek tidak pernah mengalami kejang ataupun panas tinggi. Namun saat Subjek baru bisa tengkurap, Subjek pernah terjatuh dari kasur dan lukanya masih berbekas sampai sekarang. Subjek jarang sakit dan mengkonsumsi obat, ketika sakit biasanya Subjek akan sembuh setelah tidur panjang, bahkan pernah sampai 12 jam tertidur.

Guru dan ibu Subjek mengeluhkan bahwa Subjek memiliki masalah pada pola tidurnya, suka mencubit, dan keterampilan bersosialisasinya. Ibu Subjek merasa permasalahan yang utama adalah bersosialisasi. Hal ini juga disetujui oleh guru Subjek. Pada jam istirahat, Subjek akan mendorong atau memukul anak-anak atau guru yang ada dihadapannya kemudian raut wajahnya berubah (tertawa). Subjek akan melihat ke wajah orang yang dipukulnya ketika mendapat respon (senyum atau menyapa) dari orang lain, yang mana menjadi penguat perilaku Subjek. Namun jika orang tersebut membalas memukulnya, Subjek tidak akan lagi memukul atau mendorong orang tersebut, bahkan menjauhinya. Hal tersebut menjadi punishment untuk Subjek agar tidak mengulangi perilaku memukul orang tersebut. Salah satu guru dari kelas lain menganggap perilaku ini merupakan perilaku agresi Subjek, sehingga terkadang guru Subjek membawa teman Subjek yang dipukulnya ke hadapan Subjek untuk membalas memukul Subjek.

Anak dengan ASD menunjukkan kegagalan membina hubungan interpersonal yang ditandai dengan kurangnya respon terhadap lingkungan atau kurangnya minat kepada orang atau anak yang berada di sekitarnya (Asrizal, 2016). Hal ini diperkuat dengan keadaan di sekolah dimana guru-guru Subjek kurang mengajarkan bagaimana cara memulai berhubungan dengan orang lain. Bahkan disaat jam istirahat terkadang beberapa guru bermain dengan handphone-nya sehingga Subjek duduk disamping guru tersebut untuk memperhatikan handphone tersebut. Hal ini membuat Subjek kehilangan kesempatan untuk berinteraksi dengan orang lain.

Anak dengan ASD mungkin sulit untuk bergabung dengan grup dan berteman. Terkadang hal ini mengarah pada perasaan terisolasi dan bahkan depresi (Desiningrum, 2016). Akibat dari kurangnya kemampuan Subjek dalam hal keterampilan sosial membuat Subjek kesulitan berinteraksi dengan teman-temannya. Sebagian teman-teman Subjek manjauhinya ketika Ia mendekat karena takut dipukul. Kurangnya keterampilan sosial Subjek membuat Subjek tidak dapat bergabung dengan teman-temannya saat melihat teman-temannya berkumpul dan tertawa sehingga Subjek sering duduk sendirian. Subjek sendiri mengalami keterlambatan dalam kematangan sosial. Subjek yang seharusnya memiliki kematangan sesuai dengan anak berusia 7.7 tahun ternyata masih berada pada tahap kematangan sosial anak usia 4.8 tahun. Hal ini menunjukkan bahwa kematangan sosialnya berada di bawah anak-anak seusianya dan perlu di tingkatkan, terutama dalam hal sosialisasi. Keterlamabatan kematangan sosial merupakan salah satu ciri dari ASD. Namun subjek termasuk anak dengan ASD level 1 (ringan) dimana hal ini menunjukkan bahwa kematangan social subjek masih dapat dioptimalkan.

Di sekolah luar biasa, banyak anak-anak berkebutuhan khusus yang lebih tua (SD, SMP, 
SMA, dan SMK) yang bercanda dengan temannya dengan cara saling memukul dan mendorong, kemudian mereka tertawa bersama. Ketika melihat hal tersebut Subjek terdiam di depan anak-anak tersebut dan memperhatikan mereka tidak lama kemudian Subjek memukul salah satu diantara anak-anak tersebut. Perilaku yang dilakukan oleh Subjek merupakan bentuk modeling dari perilaku kakak kelasnya dan mendapatkan respon berupa senyum dan tawa dari kakak kelasnya yang menjadi penguat perilakunya.

Modeling sendiri memiliki 4 faktor yaitu, perhatian, representasi, peniruan tingkah laku model, dan motivasi/penguatan (Alwisol, 2012). Subjek mengamati apa yang dilakukan oleh kakak kelasnya yang kemudian tersimbolisasikan diingatannya. Subjek kemudian merubah apa yang tersimbolisasi diingatannya menjadi perilaku memukul yang kemudian mendapat penguat karena banyak yang tidak membalasnya, atau menoleh ke arah Subjek.

Subjek cepat belajar dengan meniru perilaku yang dilihatnya, terlebih Subjek memiliki kecerdasan yang tergolong superior. Hal ini sesuai dengan teori Bandura yang menyatakan bahwa kebanyakan belajar terjadi tanpa penguatan yang nyata. Individu dapat mempelajari respon baru dengan melihat respon orang lain. Belajar melalui observasi lebih efisien dibandingkan dengan belajar melalui pengalaman langsung, karena melalui observasi individu dapat memperoleh respon yang tidak terhingga banyaknya (Alwisol, 2012). Belajar melalui observasi biasa disebut dengan modeling. Modeling berbeda dengan sekedar meniru. Modeling melibatkan penambahan dan atau pengurangan perilaku yang diamati, mengeneralisir berbagai pengamatan sekaligus, dan melibatkan proses kognitif (Alwisol, 2012).

\section{Diagnosis dan Prognosis}

Diagnosa pada subjek adalah 299.00 (F84.0) Autism Spectrum Disorder dengan permasalahan keterampilan sosial. Subjek memenuhi kriteria di DSM V, yaitu adanya defisit komunikasi dan interaksi sosial yang presisten, adanya keterbatasan perilaku, aktivitas dan minat, gejala-gejala tersebut timbul pada masa perkembangan awal yang semakin jelas gejalanya seiring dengan berjalannya waktu, serta menyebabkan gangguan sosial, okupasional, dan fungsi lainnya secara signifikan. Selain itu gejala ini tidak dapat dijelaskan dengan adanya disabilitas intelektual. Subjek termasuk ASD level 1(ringan) dengan permasalahan komunikasi sosial yaitu tidak bisa memulai interaksi dengan orang lain. (American Psychiatric Association, 2013).

Prognosis untuk permasalahan keterampilan sosial Subjek ialah baik. Subjek mengalami ASD pada level 1 dimana kemampuan sosial Subjek dapat ditingkatkan. Subjek masih berusia 7 tahun dan memiliki kecerdasan yang tergolong superior. Subjek memiliki keluarga yang sangat mendukung dan berperan aktif dalam mengawasi dan membantu Subjek.

\section{Intervensi dan Perubahan Perilaku}

Anak-anak yang bisa berbicara cenderung lebih mudah untuk menirukan perintah dan belajar berbagai keterampilan sosial dibandingkan dengan anak yang belum. Anak-anak yang masih nonverbal, dapat dikembangkan perilaku sosialnya seperti bersalaman, tersenyum, dan isyarat sosial lainnya. Pada indikator keterampilan sosial anak autis yang dilatih dalam intervensi ini adalah: bersalaman dan menyapa (Suharsiwi, 2015).

Ada empat fase penilaian: baseline, pelatihan keterampilan sosial, umpan balik, dan follow up (Rao et al., 2008). Pada prinsipnya pelatihan ketrampilan dapat dilaksanan melalui 4 tahap, yaitu modelling, roleplaying, performance feedback dan transfer training (Ramdhani, 1994). Tahapan-tahapan ini diulang hingga subjek mengalami perubahan. Modeling merupakan salah satu cara yang cukup efektif untuk digunakan pada anak yang mengidap ASD.

Sebelum memulai intervensi, terapis menjelaskan permasalahan dan rencana intervensi kepada orang tua dan guru. Terapis meminta keikutsertaan orang tua dan guru dalam membantu berjalannya intervensi dengan lancar. Orang tua dan guru sepakat untuk mencontohkan dan 
membiasakan L untuk menyapa orang yang ditemuinya dengan bersalaman atau melakukan tos, serta menghentikan dan menasehati L ketika L menyapa orang dengan memukulnya. Selain itu guru-guru diskeolah juga diberi pengertian mengaenai pentingnya lingkungan yang baik dalam melaksanakan intervensi ini. Oleh karena itu diperlukan kerjasama yang baik untuk menciptakan lingkungan yang kondusif dengan mengawasi dan mengambil tindakan untuk anak-anak di sekolah yang melakukan perilaku agresi dengan lebih cermat. Pelatihan keterampilan sosial yang diberikan pada L dilaksanakan di sekolah saat jam istirahat. Tahap dan perkembangan intervensi

Sesi 1: Baseline. Pada sesi ini terapis menilai keterampilan sosial dasar dari subjek dalam kegiatan yang tidak diarahkan kegiatan yang tidak diarahkan selama tiga hari berturut-turut dengan cara mengobservasi kegiatan subjek selama jam istirahat. Pada sesi ini subjek sama sekali tidak menunjukkan perilaku yang ditargetkan.

Sebelum melakukan pelatihan keterampilan sosial, terapis melakukan observasi untuk menentukan baseline keterampilan sosial dari Subjek, yang menjadi target ialah bersalaman dan menyapa dengan tos. Perilaku yang dihitung ialah perilaku dimana Subjek mennujukkan inisiatif untuk bersalaman dan menyapa. Perilaku yang dilakukan secara berulang pada orang yang sama dalam satu waktu hanya dihitung sebagai satu perilaku. Dari hasil observasi selama 3 hari didapati bahwa Subjek sama sekali tidak menunjukkan perilaku tersebut. Hasil tersebut diberitahukan kepada guru dan orang tua Subjek begitu juga rencana intervensi serta meminta bantuan dan komitmen untuk membantu berjalannya intervensi. Intervensi di mulai pada hari ke empat hingga hari ke tujuh.

Observasi untuk melihat perubahan selama intervensi dilaksanakan pada sesi transfer training. Pada sesi tersebut terapis mengamati selama 30 menit, seberapa sering subjek bersalaman dan menyapa orang lain. Hasil ini juga dipengaruhi oleh keadaan lingkungan sekitar. Pada hari ke empat intervensi banyak dari teman sekelasnya yang tidak masuk sekolah, sehingga saat jam istirahat tidak banyak orang yang bisa diajak berinteraksi.

Sesi 2: Pelatihan keterampilan sosial 1. Sesi ini terdiri dari 4 tahap yaitu, modeling, role playing, performance feedback, dan transfer training yang dilakukan selama 10 hingga 15 menit. Modeling, yaitu tahap penyajian model yang dibutuhkan peserta pelatihan secara spesifik, detil, dan sering. Pemberian modeling pada sesi ini ialah berupa gambar orang yang sedang bersalaman dan sedang melakukan tos. Subjek diminta untuk memperhatikan gambar dengan sungguh-sunguh dan menirukan apa yang ada di gambar tersebut.

Role playing, yaitu tahap bermain peran di mana peserta pelatihan mendapat kesempatan untuk memerankan suatu interaksi sosial yang sering dialami sesuai dengan topik interaksi yang ada pada gambar Disini subjek diminta untuk memeragakan apa yang telah dilihatnya dengan terapis dan seorang teman sekelasnya.

Performance feedback, yaitu tahap pemberian umpan balik. Umpan balik ini harus diberikan segera setelah peserta pelatihan mencoba agar mereka yang memerankan tahu seberapa baik ia menjalankan langkah-langkah pelatihan ini. Terapis memberikan pujian dan mengatakan bahwa yang dilakukan adalah yang benar ketika subjek dapat memeragakan dengan benar dan memberi tahu ketika subjek melakukan kesalahan.

Transfer training, yaitu tahap pemindahan ketrampilan yang diperoleh individu selama pelatihan ke dalam kehidupan sehari-hari. setelah ketiga sesi berakhir, subjek kembali ke ruangan bersama dengan teman-temannya untuk memeragakan apa yang sudah dipelajari dari sesi-sesi sebelumnya. Pada sesi ini subjek memperhatikan gambar yang tunjukkan dan dapat memerankan gambar tersebut dengan baik sehingga subjek mendapat pujian. Subjek berhasil menerapkan perilaku tersebut di sisa jam istrahat.

Pada hari pertama pelaksanaan pelatihan keterampilan sosial setelah tahap modeling hingga performance feedback dilakukan, subjek dibiarkan keluar ruangan intervensi dan 
bergabung dengan teman-temannya. Pada hari ini subjek hanya menunjukkan satu perilaku yaitu bersalaman. Pada hari berikutnya dengan prosedur yang sama, subjek menunjukkan peningkatan dengan bersamalan sebanyak 2 kali dan menyapa sebanyak 1 kali. Pada hari ke tiga intervensi subjek juga menunjukkan peningkatan dengan bersalaman sebanyak 3 kali dan menyapa sebanyak 2 kali. Pada intervensi hari terakhir yaitu hari ke empat, subjek menunjukkan penurunan karena banyak teman-teman yang tidak masuk. Subjek hanya menunjukkan perilaku bersalaman sebanyak 2 kali dan menyapa sebanyak 1 kali.

Sesi 3: Pelatihan keterampilan sosial 2. Pelaksanaan sesi ini sama dengan sesi sebelumnya. Pertama adalah modeling, yaitu tahap penyajian model yang dibutuhkan peserta pelatihan secara spesifik, detil, dan sering. Pemberian modeling pada sesi ini ialah berupa pencontohan secara langsung antara terapis dengan teman terapis yang sedang bersalaman dan sedang melakukan tos. Subjek diminta untuk memperhatikan terapis dengan sungguh-sunguh dan menirukan apa yang dilakukan oleh terapis.

Role playing, yaitu tahap bermain peran di mana peserta pelatihan mendapat kesempatan untuk memerankan suatu interaksi sosial yang sering dialami sesuai dengan topik interaksi yang ada pada gambar Disini subjek diminta untuk memeragakan apa yang telah dilihatnya dengan terapis dan seorang teman sekelasnya.

Performance feedback, yaitu tahap pemberian umpan balik. Umpan balik ini harus diberikan segera setelah peserta pelatihan mencoba agar mereka yang memerankan tahu seberapa baik ia menjalankan langkah-langkah pelatihan ini. Terapis memberikan pujian dan mengatakan bahwa yang dilakukan adalah yang benar ketika subjek dapat memeragakan dengan benar dan memberi tahu ketika subjek melakukan kesalahan.

Transfer training, yaitu tahap pemindahan ketrampilan yang diperoleh individu selama pelatihan ke dalam kehidupan sehari-hari. setelah ketiga sesi berakhir, subjek kembali ke ruangan bersma dengan teman-temannya untuk memeragakan apa yang sudah dipelajari dari sesi-sesi sebelumnya. Pada sesi ini subjek memperhatikan gerakan yang diperankan oleh terapis dan co-terapis. Subjek mampu memerankan hal yang dicontohkan oleh terapis tersebut dengan baik sehingga subjek mendapat pujian. Subjek berhasil menerapkan perilaku tersebut di sisa jam istrahat.

Sesi 4: Pelatihan keterampilan sosial 3. Pelaksanaan sesi ini sama dengan sesi sebelumnya. Pertama modeling, yaitu tahap penyajian model yang dibutuhkan peserta pelatihan secara spesifik, detil, dan sering. Pemberian modeling pada sesi ini ialah berupa pencontohan secara langsung antara teman subjek dengan teman subjek lainnya yang sedang bersalaman dan sedang melakukan tos. Subjek diminta untuk memperhatikan kedua temannya dengan sungguh-sungguh dan menirukan apa yang dilakukan oleh temannya.

Role playing, yaitu tahap bermain peran di mana peserta pelatihan mendapat kesempatan untuk memerankan suatu interaksi sosial yang sering dialami sesuai dengan apa yang telah dicontohkan oleh temannya. Disini subjek diminta untuk memeragakan apa yang telah dilihatnya dengan terapis dan seorang teman sekelasnya.

Performance feedback, yaitu tahap pemberian umpan balik. Umpan balik ini harus diberikan segera setelah peserta pelatihan mencoba agar mereka yang memerankan tahu seberapa baik ia menjalankan langkahlangkah pelatihan ini. Terapis memberikan pujian dan mengatakan bahwa yang dilakukan adalah yang benar ketika subjek dapat memeragakan dengan benar dan memberi tahu ketika subjek melakukan kesalahan.

Transfer training, yaitu tahap pemindahan ketrampilan yang diperoleh individu selama pelatihan ke dalam kehidupan sehari-hari. setelah ketiga sesi berakhir, subjek kembali ke ruangan bersma dengan teman-temannya untuk memeragakan apa yang sudah dipelajari dari sesi-sesi sebelumnya. Pada sesi ini subjek memperhatikan gerakan yang diperankan oleh dua orang teman subjek. Subjek mampu memerankan apa yang telah dicontohkan dengan baik 
sehingga subjek mendapat pujian. Subjek berhasil menerapkan perilaku tersebut di sisa jam istrahat dan bermain sejenak dengan temannya.

Sesi 5: Pelatihan keterampilan sosial 4. Pelaksanaan sesi ini sama dengan sesi sebelumnya. Pertama adalah modeling, yaitu tahap penyajian model yang dibutuhkan peserta pelatihan secara spesifik, detil, dan sering. Pemberian modeling pada sesi ini ialah berupa pencontohan secara langsung antara teman subjek dengan teman subjek lainnya yang sedang bersalaman dan sedang melakukan tos. Subjek diminta untuk memperhatikan kedua temannya dengan sungguh-sungguh dan menirukan apa yang dilakukan oleh temannya.

Role playing, yaitu tahap bermain peran di mana peserta pelatihan mendapat kesempatan untuk memerankan suatu interaksi sosial yang sering dialami sesuai dengan apa yang dicontohkan oleh temannya. Disini subjek diminta untuk memeragakan apa yang telah dilihatnya dengan terapis dan seorang teman sekelasnya.

Performance feedback, yaitu tahap pemberian umpan balik. Umpan balik ini harus diberikan segera setelah peserta pelatihan mencoba agar mereka yang memerankan tahu seberapa baik ia menjalankan langkahlangkah pelatihan ini. Terapis memberikan pujian dan mengatakan bahwa yang dilakukan adalah yang benar ketika subjek dapat memeragakan dengan benar dan memberi tahu ketika subjek melakukan kesalahan.

Transfer training, yaitu tahap pemindahan ketrampilan yang diperoleh individu selama pelatihan ke dalam kehidupan sehari-hari. setelah ketiga sesi berakhir, subjek kembali ke ruangan bersma dengan teman-temannya untuk memeragakan apa yang sudah dipelajari dari sesi-sesi sebelumnya. Pada sesi ini subjek memperhatikan gerakan yang diperankan oleh dua orang teman subjek. Subjek mampu memerankan apa yang telah dicontohkan dengan baik sehingga subjek mendapat pujian dari terapis. Subjek berhasil menerapkan perilaku tersebut di sisa jam istrahat.

Sesi 6: Evaluasi dan feedback. Pada sesi ini terapis mengevaluasi kegiatan yang telah dilakukan. Evaluasi dilakukan dengan cara observasi serta memerikan penguatan dengan memberikan pujian kepada subjek jika dia terlibat dalam interaksi sosial selama 30 menit di sisa jam istirahat. Penilaian dilakukan selama empat hari pasca intervensi. Subjek tetap menunjukkan inisiatif untuk memulai interaski dengan orang lain meskipun sesi pelatihan keterampilan sosial berakhir.

Evaluasi dan feedback dilakukan dengan cara observasi di waktu istirahat selama 30 menit dalam 4 hari berturut-turut. Subjek menerima pujian setiap kali melakukan perilaku yang seharusnya sebagai feedback. Hasil evaluasi menunjukkan bahwa pada hari pertama evaluasi Subjek melakukan salaman sebanyak satu kali dan menyapa 1 kali pada hari ini juga banyak teman-temannya yang tidak masuk. Pada hari ke dua, Subjek hanya bersalaman satu kali, pada hari ini banyak teman-temannya yang tidak masuk, bahkan lebih banyak dari sebelumnya. Pada hari ketiga Subjek menunjukan perilaku bersalaman sebanyak 2 kali dan menyapa sebanyak 1 kali. Pada hari terakhir evaluasi perilaku bersalaman Subjek muncul sebanyak 3 kai dan menyapanya 1 kali. Pada hari terakhir ini, ada beberapa kakak kelas yang mengajak Subjek bersalaman dan Subjek melanjutkan dengan mengajak kakak kelas yang lainnya untuk bersalaman.

Selesai melakukan evaluasi, terapis menjelaskan perubahan yang terjadi pada perilaku Subjek kepada orang tua dan gurunya. Orang tua dan guru diminta untuk tetap membiasakan Subjek untuk bersalaman dan menyapa orang yang ditemuinya meskipun intervensinya sudah berakhir.

Sesi 7: Terminasi. Terapis dan subjek mengakhiri proses terapi. Dalam sesi ini, Terapis meminta orang tua subjek untuk dapat memfokuskan diri kepada tujuan yang akan dicapai serta memotivasi subjek atas apa yang telah dilakukan pada proses terapi untuk dapat diaplikasikan dan menginternalisasikan dalam diri subjek. Tujuan dari sesi ini ialah mengakhiri proses terapi dan menjadikan subjek tidak bergantung dengan terapis yang telah mendampingi selama proses 
terapi. Orang tua dan guru dari subjek menyetujui dan mengatakan akan terus berkomitmen untuk fokus dan memotivasi subjek dalam meningkatkan keterampilan sosialnya.

Follow up. Evaluasi perubahan perilaku yang dilaksanakan dua minggu pasca intervensi untuk memastikan subjek tetap memunculkan perilaku yang dipelajari selama intervensi. Pada saat follow up, hasil observasi menunjukkan bahwa subjek tetap memunculkan perilaku yang telah diajarkan kepadanya.

Saat follow up, hasil yang didapat kan adalah Subjek 1 kali mengajak salaman. Selama 2 minggu setelah intervensi berakhir ada beberapa kejadian yang menghambat perkembangan Subjek. Ketika Subjek lepas dari pengawasan gurunya ada kakak kelas yang menarik tangan Subjek untuk memukul orang-orang disekitarnya dan hal ini di contoh oleh Subjek sampai gurunya melihat dan menegur kakak kelasnya tersebut. Hal ini merupakan kejadian di luar kendali terapis dan menjadi salah satu penghambat. Namun, meski ada kakak kelas yang mengajarkannya memukul, beberapa kakak kelas yang lain telah terbiasa menyapa dan bersalaman dengan Subjek sehingga hal ini dapat mengurangi efek dari kejadian sebelumnya. Guru Subjek mengatakan selama 2 minggu setelah intervensi, Subjek tetap menunjukkan inisiatif di sekolah. Ibu dari Subjek juga mengatakan bahwa Subjek menunjukkan perkembangan ketika bertemu dengan sekumpulan ibu-ibu, ibu dari Subjek menyuruh Subjek untuk bersalaman dengan satu orang, namun Subjek melanjutkan bersalaman dengan semua orang yang ada disana. Perubahan perilaku subjek sebelum dan setelah intervensi dapat dilihat pada Gambar 1 .

\section{Pembahasan}

Intervensi pelatihan keterampilan sosial menunjukkkan perubahan perilaku pada subjek. Subjek yang semula tidak bisa memulai interaksi dengan orang lain mulai menunjukkan inisiatif untuk menyapa dengan tos atau bersalaman. Sebelum memulai intervensi, dilakukan edukasi kepada ibu dan guru dari subjek mengenai keadaan subjek. Ibu dan guru subjek diminta untuk bekerja sama dengan memberikan dukungan dan turut membiasakan perilaku menyapa dan bersalaman dengan subjek. Keberhasilan intervensi ini juga dibantu oleh teman-teman subjek yang ikut mencontoh perilaku yang diajarkan pada subjek, sehingga saat bertemu subjek terkadang temannya menyapa terlebih dahulu. Pelatihan keterampilan sosial menggunakan prinsip modeling. Penelitian telah menunjukkan bahwa pemodelan tidak hanya mengajarkan perilaku baru kepada anak-anak dengan autisme tetapi juga dalam mempromosikan generalisasi dan pemeliharaan perilaku ini (Charlop-christy et al., 2000). Oleh karena itu terapis bekerjasama dengan guru dan orang tua untuk tetap mencontohkan dan membiasakan perilaku menyapa daan bersalaman untuk memelihara perilaku sosial subjek diluar sesi intervensi.

Adanya perubahan yang terjadi dalam subjek yaitu mendapatkan banyak teman

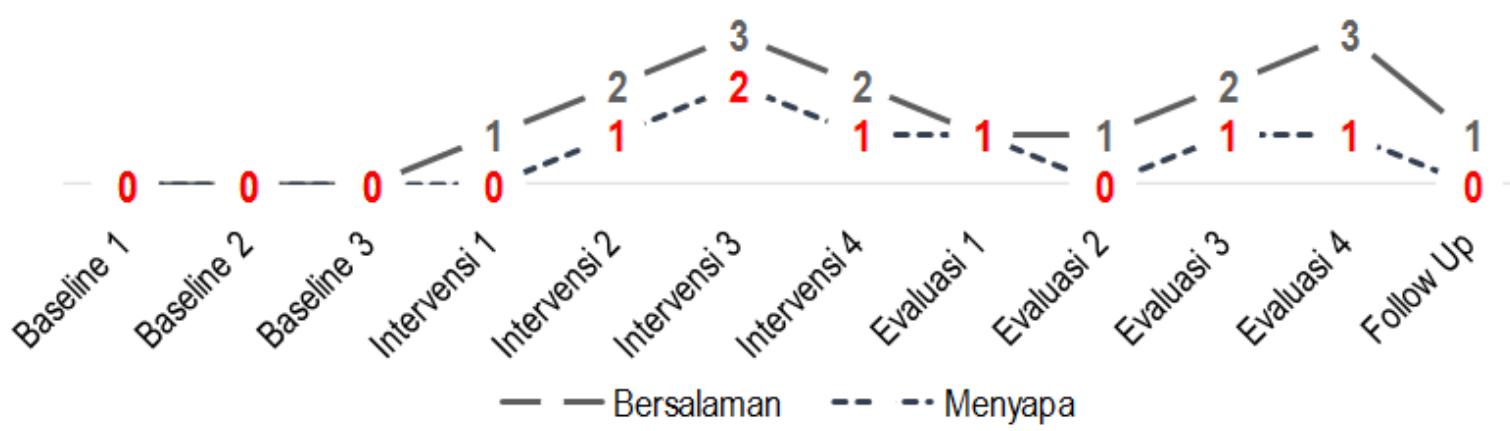

Gambar 1. Proses intervensi keterampilan sosial. 
dapat membentuk rasa percaya diri anak dan meningkatkan keterampilan sosialnya serta menumbuhkan emosi yang sehat dan peduli pada sesamanya (Suharsiwi, 2015). Teman-teman yang awalnya menjauhinya mulai mengajaknya bermain bersama meskipun subjek belum bisa bermain bersama dalam waktu yang lama.

Intervensi ini menggunakan dua jenis modeling, yaitu modeling simbolis dimana meniru dari media seperti film, video dan media lainnya; dan modeling secara langsung dengan penokohan secara nyata seperti terapis, guru, anggota keluarga atau orang yang dikagumi subjek (Damayanti \& Aeni, 2016). Pemodelan simbolis dilaksanakan untuk menarik perhatian subjek, namun subjek yang mudah bosan memerlukan cara lain yaitu dengan pemodelan secara langsung. Pemodelan secara langsung lebih mudah di contoh oleh subjek untuk di terapkan di roleplay dan di sisa jam istirahat ketika subjek berkumpul bersama dengan teman-temannya.

Modeling memiliki 4 faktor yaitu, perhatian, representasi, peniruan tingkah laku model, dan motivasi atau penguatan (Alwisol, 2012). Subjek mengamati apa yang dicontohkan didepannya kemudian merubah apa yang tersimbolisasi diingatannya menjadi perilaku bersalaman dan menyapa atau tos yang kemudian mendapat penguat dengan pujian dari terapis. Proses ini sama dengan tahap yang ada di pelatihan keterampilan sosial, yaitu modeling, roleplaying, performance feedback, dan ditambah dengan transfer training untuk menyalurkan apa yang dipelajari ke kehidupannya.

\section{Simpulan}

Hasil intervensi sesuai dengan target yang telah ditentukan oleh terapis dan sesuai dengan kebutuhan subjek. Saran untuk pihak keluarga ialah tetap memberi semangat, mengajarkan dan mencontohkan perilaku untuk meningkatkan keterampilan sosial subjek. Pihak sekolah juga disarankan untuk melakukan hal yang sama, yaitu mengajarkan dan mencontohkan perilaku berkaitan dengan keterampilan sosial. Guru-guru juga bisa mengajak murid-murid yang ada untuk melakukan hal ini. Pihak sekolah diharapkan dapat melakukan pengawasan dan mengajari perilaku yang baik pada murid-murid yang suka melakukan perilaku agresi terutama di jam istirahat karena perilaku tersebut dapat dicontoh oleh murid-murid lain. Selain itu, beberapa staf diharapakn untuk tidak lagi menjewer murid-murid yang menyalahi aturan, lebih baik bila memperingati dengan cara yang lebih halus seperti menasehati dan mencontohkan. Untuk terapis atau peneliti berikutnya bisa melakukan intervensi yang berfokus pada bagaimana menciptakan lingkungan yang baik di sekolah luar biasa agar dapat meningkatkan keterampilan sosial anak-anak dengan kebutuhan khusus di sekolah ini.

\section{Referensi}

Alwisol, M. (2012). Psikologi Kepribadian (Edisi Revisi) (11th ed.). Malang: UMM Press.

American Psychiatric Association. (2013). Diagnostic and Statistical Manual of Mental Disorders Fifth Edition. Arlington. https://doi.org/10.1176/appi.books.9780890425596.744053

Asrizal. (2016). Penanganan Anak Autis dalam Interaksi Sosial. Jurnal PKS, 15 (1), 1-8.

Charlop-christy, M. H., Le, L., \& Freeman, K. A. (2000). A Comparison of Video Modeling with In Vivo Modeling for Teaching Children with Autism, 30(6), 537-538.

Damayanti, R., \& Aeni, T. (2016). Rika Damayanti, Tri Aeni, 3(1), 1-10.

Desiningrum, D. R. (2016). Psikologi anak berkebutuhan khusus. Yogyakarta: Psikosain.

Gelbar, N., \& Buggey, T. (2012). Video self-modeling as an intervention strategy for individuals with Autism Spectrum Disorders, (April 2018). https://doi.org/10.1002/pits.20628

Golzari, F., \& Alamdarloo, G. H. (2015). The Effect of a Social Stories Intervention on the Social Skills of Male Students With Autism Spectrum Disorder, (December). https://doi.org/10.1177/2158244015621599

Jhon, W. S. (2012). Life Span Development. (N. I. Sallama, Ed.), Erlangga.

Ramdhani, N. (1994). Pelatihan Keterampilan Sosial untuk Terapi Kesulitan Bergaul. Universitas Gajah Mada. Rao, P. A., Beidel, Æ. D. C., \& Murray, Æ. M. J. (2008). Social Skills Interventions for Children with Asperger's Syndrome or High- Functioning Autism: A Review and Recommendations Social Skills Interventions for Children with Asperger's Syndrome or High-Functioning Autism: A Review and Recommendations, (March). https://doi.org/10.1007/s10803-007-0402-4 
Suharsiwi. (2015). Pengembangan Model Pembelajaran Keterampilan Sosial Anak Autis di TK B, 10(1), 1-8. Weiss, M. J., \& Harris, S. L. (2001). Teaching Social Skills to People With Autism. Behavior Modification, 25(5), $785-802$

Williams, S., Kathleen, W. Æ., \& Scahill, L. (2007). Social Skills Development in Children with Autism Spectrum Disorders: A Review of the Intervention Research Social Skills Development in Children with Autism Spectrum Disorders: A Review of the Intervention Research, (March 2016). https://doi.org/10.1007/s10803-006-0320-x 